\title{
Ozonetherapy for equine laminitis [abstract]
}

\section{Eduardo Flores-Colin, Susana Gabriela Gayon-Amaro}

Ozein Vet Klinike

\section{ABSTRACT}

\section{○ OPEN ACCESS}

\section{Citation}

Flores-Colin E, Gayon-Amaro SG. Ozonetherapy for equine laminitis [abstract]. Proceedings of The World Conference on Ozone Therapy in Medicine, Dentistry and Veterinary. Ancona (Italy). September 22nd - 23rd - 24th , 2017. J Ozone Ther. 2019;3(4):16-17. doi: 10.7203/ jo3t.3.4.2019.15421

\section{Academic Editor}

Jose Baeza-Noci,

School of Medicine, Valencia University, SPAIN

\section{Editor}

World Federation of Ozone Therapy, Bolgna, ITALY

\section{Received}

June 17, 2019

\section{Accepted}

December 08, 2019

\section{Published}

December 30, 2019

\section{Intellectual Property}

Eduardo Flores-Colin.

This is an open access article distributed under the terms of the Creative Commons Attribution License (CC BY 4.0), which permits unrestricted use, distribution, and reproduction in any medium, provided the original author and source are credited.

\section{Author Information}

Email: mvzeduardo@msn.com
Purpose: To teach and to demonstrate the efficiency of ozone therapy in horses with chronic laminitis.

Patients and methods: Six horses with chronic laminitis were treated with two ozonetherapy techniques. All horses were $4 / 5$ or $5 / 5$ grade lameness [1], showed severe pain in the fore limbs and were no able to move.
- Inyectable distilled water

- 14G Catheter needles

- $500 \mathrm{~mL}$ blood transfusion bags

- Venoset

- Gloves
- $60 \mathrm{~mL}$ syringes

- $2 \%$ Lidocaine

- Medicinal oxygen

- Ozone generator

- $21 \mathrm{G}$ butterfly needles
1 Spanish and 2 Quarter horses were treated with hyperperfusion technique via cephalic vein injecting $60 \mathrm{~mL}$ of distilled water previously ozonized with $85 \mathrm{mcgr} / \mathrm{mL}$ of the oxygen-ozone mixture.

1 Thoroughbred, 1 Appaloosa and 1 Quarter horses were treated with the hyperperfusion technique via the cephalic vein and with major autohemotherapy [2,3] extracting $250 \mathrm{~mL}$ of blood in a transfusion bag and ozonizing it with $250 \mathrm{~mL}$ of the ozone-oxygen mixture with concentration of 23-25 $\mathrm{mcgr} / \mathrm{mL}$.

4 horses were treated weekly for 4 sessions (1 Spanish, 2 Quarter and 1 Thoroughbred). Those patients improved between 90 and $95 \%$. The grade of lameness were between $1 / 5$ and 2/5 after treatment.

2 horses (1 Quarter and 1 Appaloosa) were treated once, they did not improved as they were not evaluated nor treated with the established protocol.

Discussion: Compared to conventional treatments [3], ozonetherapy yielded better results in time and quality of recovery.

Conclusion: Ozonetherapy is the best choice we have developed for chronic laminitis in horses.

\section{References:}

1. Stashaka TA. Lameness in horses. Fifth Edition. USA. Lippincott Williams \& Wilkins; 2002.

2. Menéndez CS, González AR, Ledea LO, Hernández RF, León FO, Díaz GM. Ozono: Aspectos básicos y aplicaciones clínicas. Primera edición. Cuba. Editorial CENIC Centro Nacional de Investigaciones Científicas; 2008. 
3. Bocci V, Borrelli E, Zanardi I, Travagli V. Oxygen-ozone therapy is a crossroad. Rev. Esp. de Ozono. 2011;1(1):74-86.

4. Hinchcliff KW, Kaneps AJ, Geor RJ, Equine Sports Medicine \& Surgery. Second Edition. USA. Saunders Elsevier; 2014. p 262-265 